\title{
An Experimental and Numerical Approach to Multifunctional Urban Surfaces through Blue Roofs
}

\author{
Carlos Rey-Mahía ${ }^{1, *(\mathbb{D})}$, Felipe Pedro Álvarez-Rabanal ${ }^{1}$, Luis Angel Sañudo-Fontaneda ${ }^{1,2}$ (]) \\ Mario Hidalgo-Tostado ${ }^{1}\left(\mathbb{1}\right.$ and Antonio Menéndez Suárez-Inclán ${ }^{1}$
}

1 GICONSIME Research Group, Department of Construction and Manufacturing Engineering, INDUROT Research Institute, University of Oviedo, 33600 Mieres, Spain; alvarezfelipe@uniovi.es (F.P.Á.-R.); sanudoluis@uniovi.es (L.A.S.-F.); UO243988@uniovi.es (M.H.-T.); UO225669@uniovi.es (A.M.S.-I.)

2 Centre for Agroecology, Water and Resilience, Coventry University, Ryton Gardens, Coventry CV8 3LG, UK

* Correspondence: UO236881@uniovi.es; Tel.: +34-985-458196

\section{check for}

updates

Citation: Rey-Mahía, C.;

Álvarez-Rabanal, F.P.;

Sañudo-Fontaneda, L.A.; Hidalgo-Tostado, M.; Menéndez Suárez-Inclán, A. An Experimental and Numerical Approach to Multifunctional Urban Surfaces through Blue Roofs. Sustainability 2022, 14, 1815. https://doi.org/ $10.3390 /$ su14031815

Academic Editor: Baojie He

Received: 14 December 2021

Accepted: 26 January 2022

Published: 5 February 2022

Publisher's Note: MDPI stays neutral with regard to jurisdictional claims in published maps and institutional affiliations.

Copyright: (C) 2022 by the authors. Licensee MDPI, Basel, Switzerland. This article is an open access article distributed under the terms and conditions of the Creative Commons Attribution (CC BY) license (https:// creativecommons.org/licenses/by/ $4.0 /)$.

\begin{abstract}
Uncontrolled urban growth causes a number of problems associated with land use, stormwater management and energy generation. Sustainable Urban Drainage Systems (SUDS) are positioned as an alternative to traditional constructive solutions, contributing towards the generation of multifunctional urban spaces for efficient stormwater management and energy consumption reduction. Nevertheless, this combined goal calls for a deeper understanding of the heat transfer processes that govern the temperature performance in SUDS in order to be further validated as infrastructure to house renewable energy elements. This study intends to determine the thermal properties of two types of blue roofs under extreme conditions of performance (wet and dry), depicting the operation features of their layers and comparing their performances based on the materials used. With this aim, a hybrid experimental methodology, combining laboratory and numerical modelling, was designed using standardized equipment (ISO 8990:1994 and ASTM C1363-05), improving previous methods proposed in the study of the thermal properties of SUDS. The section with expanded clay improved the hydraulic capacity by $4.8 \%$. The section without expanded clay increased its thermal transmittance value by $64.9 \%$ under wet conditions. It was also found that the presence of water increased the equivalent thermal conductivity in both sections by $60 \%$.
\end{abstract}

Keywords: blue roof; energy-water nexus; hot-box test; nature-based solutions (NBS); low impact development (LID); stormwater constructed measures (SCM); green infrastructure (GI); water sensitive urban design (WSUD)

\section{Introduction}

Cities across the globe have seen their populations increase by up to 1.1 billion people [1]. This tendency is estimated to continue over the next decades, causing a raise of 2.5 billion inhabitants by 2050 [2]. This phenomenon poses present and future challenges such as the enhancement of water management in urban environments [3], the search for new renewable energy sources and the optimization of urban space [4]. The latter being identified as a key factor for sustainable development in consolidated urban areas [5]. These challenges are outlined in the Sustainable Development Goals (SDGs) receiving special attention in Goal 11 related to sustainable cities and communities [6]. Moreover, buildings have been pinpointed as a cornerstone urban feature to cut energy demand in urban areas as they represent a significant amount of the total energy consumption in cities. For instance, air-conditioning and domestic hot water stand for $80 \%$ of the amount of energy consumed by a standard building [7], evidencing the need for the implementation of renewable energy systems within or adjacent to these urban structures.

Along these lines, the European Union (EU) encourages the adoption of Nature-based Solutions (NBS) at all territorial levels, including the urban environment [8]. Sustainable 
Urban Drainage Systems (SUDS) are highlighted as fundamental elements to help cities transition towards regenerative philosophies under this defiant context of change [9]. SUDS are a set of techniques enclosed in the Low Impact Development (LID) and the Water Sensitive Urban Design (WSUD) ethos [10]. Thus, it is necessary to strengthen the knowledge about the climate-land-water-energy nexus [11], paving the path for new studies that delve into the relations between these elements [12].

A few authors explored the water-energy nexus, combining SUDS and renewable energy techniques from a thermal harnessing viewpoint, with the majority of these investigations focused on the use of ground source heat pump (GSHP) alongside permeable pavement systems (PPS) [13-15]. Recent studies have examined the potential match between GSHP and wet swales [16], as well as the long-term temperature behavior of vegetated swales in the field [17]. The abovementioned studies revealed promising results for the future development of multifunctional surfaces, housing energy and stormwater management techniques.

Nevertheless, the SUDS utilized within the structure of a building have not been investigated from this particular angle, which exemplifies a knowledge gap in the field. Green and blue roofs are, perhaps, the most used SUDS in buildings. Therefore, they are appropriate candidates to be developed as potential multifunctional surfaces for water and energy management. In this regard, roofs have been spotted as one of the main causes of surface waterproof in urban environments [18]. Additionally, green roofs have proven to be efficient urban elements which reduce the heat island effect (HIE) by controlling the temperature of the roof of a building [19]. These SUDS allow temperature regulation, providing heating in winter conditions and cooling in summer conditions [20]. In addition, green and blue roofs mimic the natural hydrological processes [21], enhancing the development of new urban habitats [22].

The present research targeted blue roofs as one of the key SUDS based in buildings as well as one of the most investigated and extended across the world [23]. Hence, this study tackles one of the most significant knowledge gaps in relation with the water-energy nexus through the implementation of SUDS. Besides, previous experiences outlined in Charlesworth et al. [4] highlighted the need to further investigate the thermal properties provided by the most commonly used materials in the cross-section of SUDS. There is also a lack of comprehensive studies showing the combined performance of these materials under wet conditions, which represents one of the extreme operation scenarios in SUDS [24]. Consequently, this research elaborates on these previously described gaps, studying the thermal performance of blue roofs, using several materials which are widely utilized in blue roofs such as limestone, expanded clay aggregates, geotextiles and modular tanks.

A numerical analysis of the blue roofs was carried out, applying a hybrid methodology used by previous authors such as del Coz Díaz et al. [25] in order to study the thermal properties of construction materials. These numerical models allowed the in depth study and simulation of the heat transfer phenomena developed in the system [26]. With this aim, the research raised the following specific objectives:

- Development of a laboratory-based methodology using standardized tests in order to determine and measure the key thermal parameters in the different layers of wet and dry blue roofs. This method could be transferred to other SUDS.

- Identification and measurement of the effect of lightweight materials utilized in blue roofs such as expanded clay.

- Assessment of the thermal properties (i.e., transmittance and conductivity) of the blue roof cross-sections studied in the models.

- Obtainment of the thermal properties of the materials forming the standard sections of the roofs studied using numerical models, Design of Experiments (DOE) and MultiObjective Genetic Algorithm methodologies (MOGA). 


\section{Materials and Methods}

\subsection{Materials and Experimental Set-Up}

Blue roofs consist of four main layers based on the Philadelphia Water Department designs [27]: gravel/aggregate layer, geotextile, drainage layer, and a suitable waterproofing roof membrane. These sections share all layers with the structure of a regular green roof except the surface layer, where vegetation and growth substrate are usually located. This surface layer is replaced by a gravel/aggregate layer in the case of blue roofs [3]. This kind of structure has been widely utilized both in the laboratory and in the field, achieving prime results from a stormwater management standpoint [28]. Therefore, this research used the following materials as layers for the laboratory blue roof models:

- Material 1: limestone aggregate 10/20 mm particle size diameter, $2690 \mathrm{~kg} / \mathrm{m}^{3} \mathrm{bulk}$ density and 35\% porosity. This material was included in sections type 1 and 2 as surface layer, as well as, in type 1 in the sub-base layer (Figure 1).

- Material 2: Atlantis Flo-Tank ${ }^{\circledR}$ lightweight modular tank structural system with $450 \mathrm{~mm}$ height, $685 \mathrm{~mm}$ length and $408 \mathrm{~mm}$ width. These modular tank systems provide up to $90 \%$ of voids in volume and were implemented between the surface layer and the sub-base (Figure 1).

- Material 3: expanded clay 10/20 mm particle size diameter, $275 \mathrm{~kg} / \mathrm{m}^{3}$ bulk density and $34 \%$ porosity. This material has a higher porosity and lower density due to its properties gained through an industrial manufacture process, which confers it a vitrified surface [29].

\section{Blue Roof Type 1}

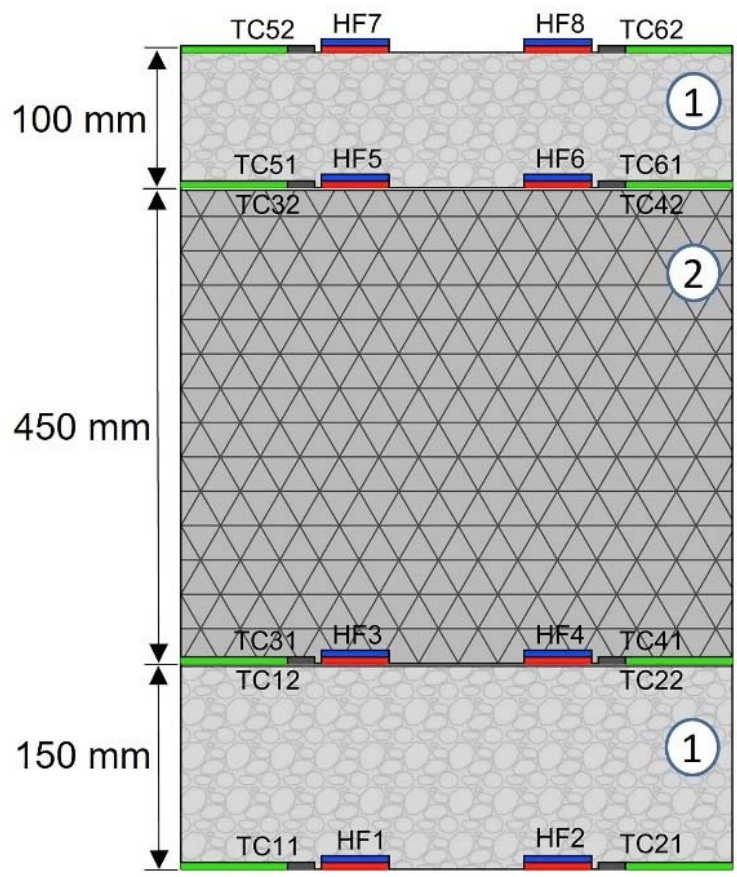

\section{Blue Roof Type 2}

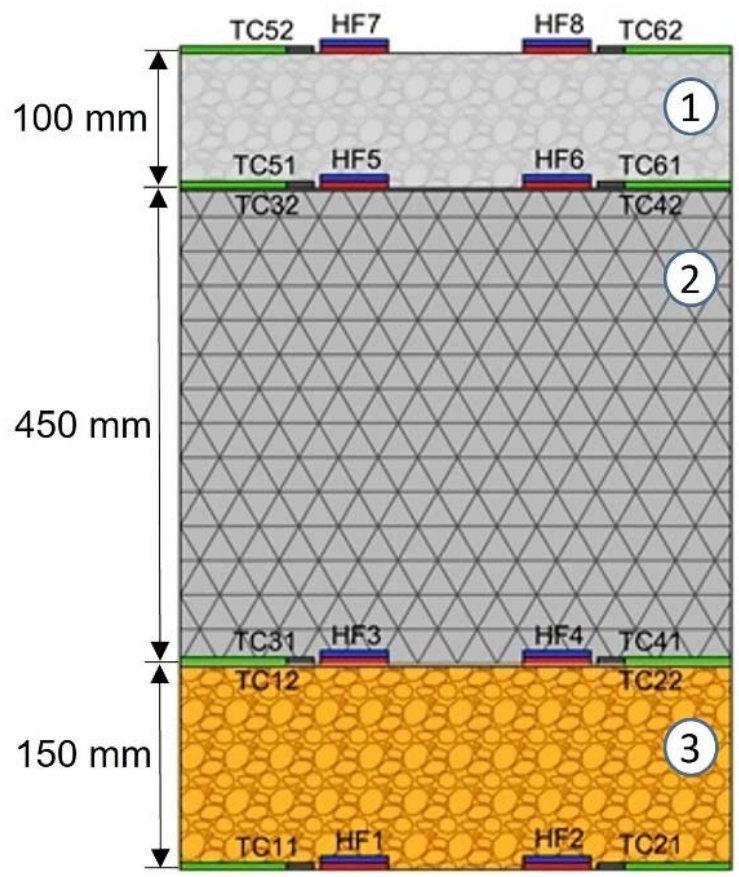

Figure 1. Types of blue roof models with details of the materials utilized (1-Limestone aggregates, 2-Atlantis' Flo-Tank $\left.{ }^{\circledR}, 3-E x p a n d e d ~ c l a y\right)$.

A geotextile is placed between all layers (surface-modular tank and modular tanksub-base interfaces) with the aim to separate them and to filter the water. The geotextile consists of short polyester fibers $150 \mathrm{~g} / \mathrm{m}^{2}$, which are non-woven, and have a thickness of $1.0 \pm 0.2 \mathrm{~mm}$. 
The equipment deployed to determine heat transfer under steady-state conditions consisted of a climate generator unit and a calibrated hot-box. The first device allows one to control the temperature values in an enclosed ambience through the provision of heating, cooling and moisture. The hot-box is connected to this device, delivering a $1 \mathrm{~m}^{3}$ space for the controlled climatic conditions. The abovementioned equipment operates in accordance with the standards ISO 8990:1994 [30] and ASTM C1363-05 [31].

The cross-sections presented in this research (Figure 1) were installed in the test box, resting on top of the hot-box (Figure 2), while being isolated from the external environment by means of a $10 \mathrm{~cm}$ layer of a extruded polystyrene with a low thermal conductivity $(0.033 \pm 0.003 \mathrm{~W} / \mathrm{mK})$. Sensors consisted of 8 type $\mathrm{K}$ thermocouples $\left(\mathrm{TC}_{\mathrm{xy}}\right)$ and 8 heat flux Hukseflux HFP01 $\left(\mathrm{HF}_{\mathrm{x}}\right)$ that were installed at the upper and lower interfaces in all layers (Figure 1), allowing the collection of temperature and heat flux, respectively. Heat flux plate HFP01 is a sensor usually utilized for heat flux measurements in soil as well as through walls and building envelopes. The sensor specifications are as follows: Sensitivity (nominal): $60 \times 10^{-6} \mathrm{~V} /\left(\mathrm{W} / \mathrm{m}^{2}\right)$; Sensor thermal resistance: $71 \times 10^{-4} \mathrm{~K} /\left(\mathrm{W} / \mathrm{m}^{2}\right)$; Rated operating temperature range: -30 to $+70{ }^{\circ} \mathrm{C}$; Measurement range: -2000 to $+2000 \mathrm{~W} / \mathrm{m}^{2}$. In addition, thermal resistance and thermal transmittance were calculated following the operational instructions for the equipment previously depicted in the standards [30,31]. Data acquisition from the tests was carried out by means of the TRSYS equipment by Hukseflux, shown in Figure 2, coupling the measurements from the thermocouples with the data registered by the heat flux sensors, providing the temperature differential.

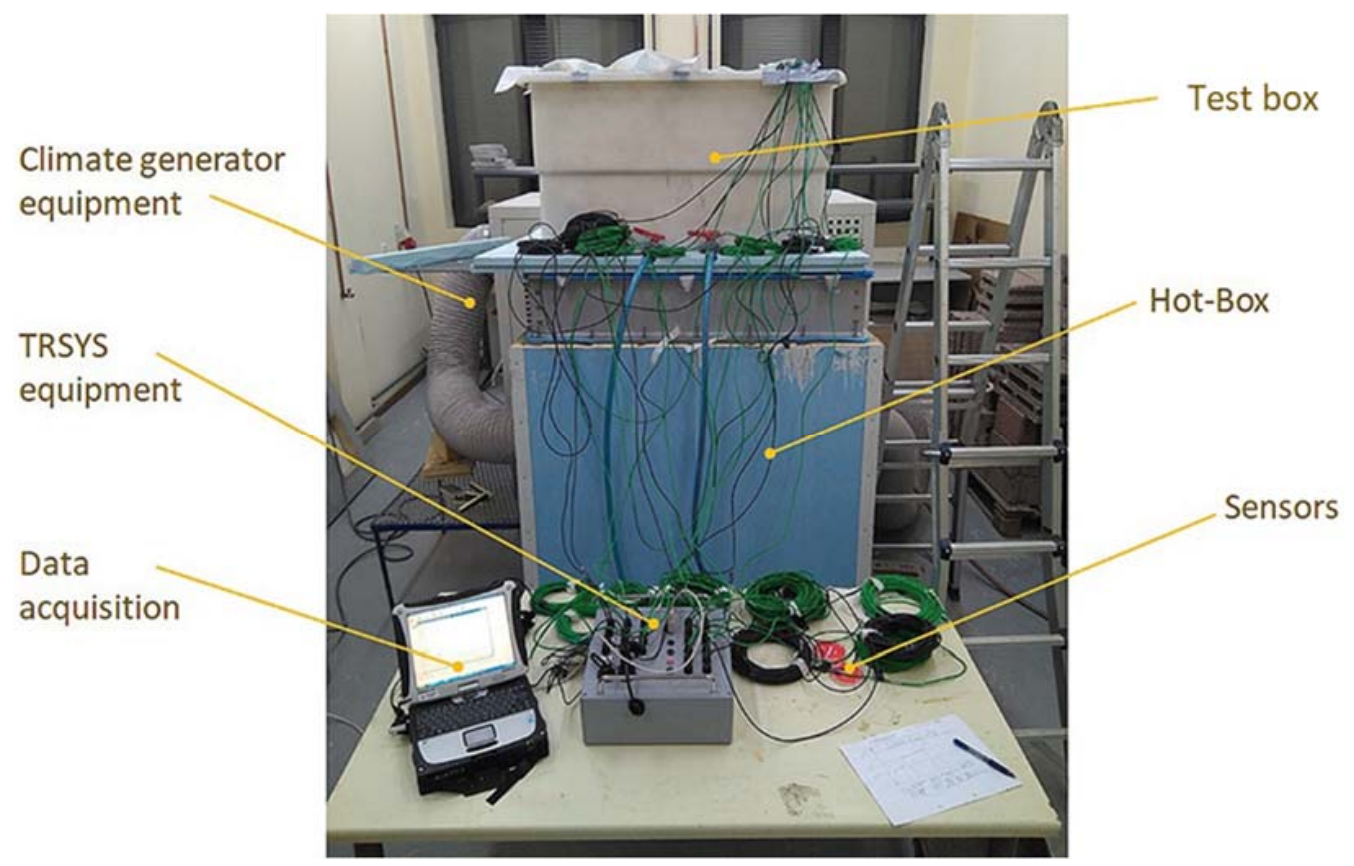

Figure 2. Experimental set-up.

The thermal transmittance is obtained using Equation (1) based on the simultaneous measurement of the average heat flux $(\Phi)$ and the temperature difference $(\Delta T)$ registered in the thermocouples. Once the thermal transmittance is calculated, the thermal resistance and the equivalent thermal conductivity of the whole section can be estimated using Equations (2) and (3).

$$
\begin{gathered}
\mathrm{U}\left[\mathrm{W} / \mathrm{m}^{2} \mathrm{~K}\right]=\Phi\left[\mathrm{W} / \mathrm{m}^{2}\right] / \Delta \mathrm{T}[\mathrm{K}] \\
\mathrm{U}^{-1}=\mathrm{R}_{\mathrm{tot}}=\mathrm{R}+\mathrm{R}_{\text {down }}+\mathrm{R}_{\mathrm{up}} \\
\lambda_{\text {eq }}=\mathrm{a} / \mathrm{R}
\end{gathered}
$$


where:

$\mathrm{R}_{\text {down }}\left[\mathrm{m}^{2} \mathrm{~K} / \mathrm{W}\right]$, corresponds to the thermal resistance at the bottom part of the box, which is 0 in this case.

$R_{u p}\left[m^{2} K / W\right]$, applies for the thermal resistance of the upper part of the blue roof.

$\mathrm{R}\left[\mathrm{m}^{2} \mathrm{~K} / \mathrm{W}\right]=\mathrm{R}_{\text {layer1 }}+\mathrm{R}_{\text {layer2 }}$, describes the thermal resistance excluding the upper and bottom parts.

$\mathrm{R}_{\text {tot }}\left[\mathrm{m}^{2} \mathrm{~K} / \mathrm{W}\right]$, corresponds to the total thermal resistance.

$a[m]$, represents the total thickness of the blue roof model.

$\lambda_{\text {eq }}[\mathrm{W} / \mathrm{mK}]$, represents the equivalent thermal conductivity of the blue roof laboratory model.

\subsection{Experimental Methodology}

The experimental methodology consisted of the simulation of the two types of blue roofs outlined in Figure 1 under dry and wet conditions. Dry conditions were simulated without the presence of water, while wet conditions were achieved by the addition of water, keeping a constant presence of water up to the surface layer (Figure 3). To reach this water level, $158.0 \pm 0.1 \mathrm{~L}$ were required for type 1 and $160.0 \pm 0.1 \mathrm{~L}$ for type 2 . Once the tests were finalized, $135.0 \pm 0.1 \mathrm{~L}$ of water were extracted from the models.
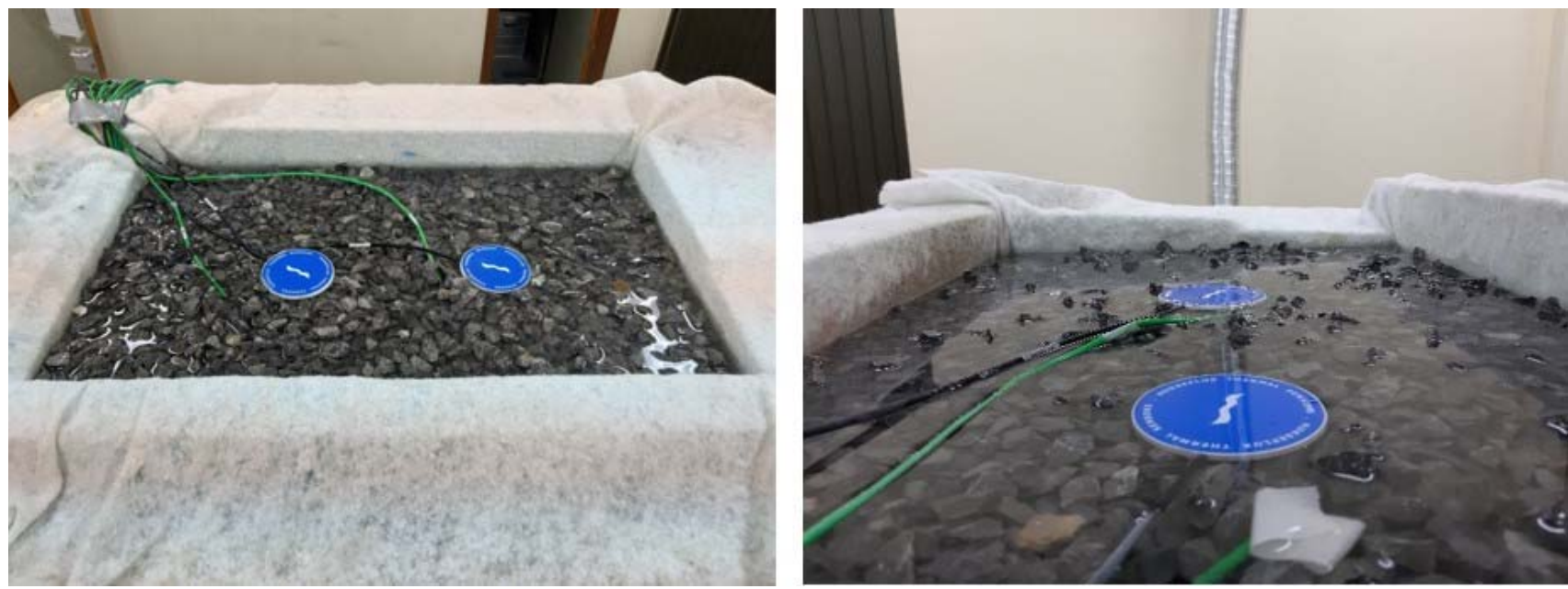

Figure 3. Schematic view of the water level in the surface layer.

A series of thermal ramps were programmed in the climatic generator equipment in order to carry out the thermal tests. These tests started at $20{ }^{\circ} \mathrm{C}$, given that this was the ambient temperature in the laboratory. The temperature was progressively raised up to $55^{\circ} \mathrm{C}$. It took $\mathrm{E}(46.5 ; 9.5)$ hours to reach this temperature, as the test was developed gradually to achieve a stable heat flow throughout the section.

The roof stabilized after reaching $55^{\circ} \mathrm{C}$, ensuring that the steady-state was achieved; Then, the data were registered during the next $10 \mathrm{~h}$ for the subsequent calculation of the thermal properties of the roof. These data were recorded using two heat flux sensors and two thermocouples at each measuring point, collecting data every $10 \mathrm{~min}$.

A test temperature of $55^{\circ} \mathrm{C}$ was selected since the standards (ISO 8990:1994 [30] and ASTM C1363-05 [31]) used to operate the equipment established that the temperature gradient between the outside and the inside of the roof must be greater than $15^{\circ} \mathrm{C}$ at all times. The reason for this is to ensure the reliability of the thermal transmittance and the equivalent thermal conductivity values, according to the abovementioned standards.

\subsection{Numerical Models}

Finite element analysis (FEM), using the ANSYS Workbench 2021R2 software was utilized to assess the thermal behavior of the blue roofs. For this purpose, 2D models of the two studied cross-sections were developed, as shown in Figure 1. 
The size of the mesh using hexahedral elements was calculated to be $10 \mathrm{~mm}$. It was modelled using PLANE293, which is a flat element with 8 nodes, with a single degree of freedom, which is the temperature at each node. This element is suitable for steady-state analysis [32]. The mesh size in the contact zones between the different materials was minimized by means of the inflation tool using the following parameters: $5 \mathrm{~mm}$ maximum thickness, a number of layers of 10 and a growth rate of 1.2.

The thermal steady-state analysis was developed by establishing an adiabatic behavior on the side walls of the studied cross-sections as boundary conditions for the model. Furthermore, convection was modelled on the upper face of the roof, using an ambient temperature of $20{ }^{\circ} \mathrm{C}$, and a convective surface coefficient of $5.0 \mathrm{~W} / \mathrm{K} \mathrm{m}^{2}$, following the Annex C in ISO 6946 [33]. The temperature values obtained experimentally at the top and bottom parts of the roof were used as input data for the FEM model. This model, used in previous works [34], was used and it provides errors below a threshold of $2 \%$.

Heat transfer by conduction occurs through the contact points. On the other side, heat transfer by convection takes place across the interface of the different layers. If heat transfer by radiation is not considered, heat transfer by conduction between two surfaces can be defined as (4) [35]:

$$
\mathrm{Q}_{\mathrm{TCC}}=\mathrm{k}_{\mathrm{TCC}} *\left(\mathrm{~T}_{\mathrm{c}, \mathrm{T}}-\mathrm{T}_{\mathrm{c}, \mathrm{C}}\right)
$$

where $\mathrm{Q}_{\mathrm{TCC}}$ is the heat flux per unit area in the interlayer $\left(\mathrm{W} / \mathrm{m}^{2}\right)$; $\mathrm{k}_{\mathrm{TCC}}$ is the thermal contact conductance coefficient $\left(\mathrm{W} / \mathrm{m}^{2}{ }^{\circ} \mathrm{C}\right) ; \mathrm{T}_{\mathrm{c}, \mathrm{T}}$ and $\mathrm{T}_{\mathrm{c}, \mathrm{C}}$ are the temperatures of the contact points on the target and contact surfaces. Parikh et al. [35] recommended a value for the thermal contact conductance coefficient of $2 \mathrm{~kW} / \mathrm{m}^{2}{ }^{\circ} \mathrm{C}$. This value was selected for this research in order to take into account the presence of microscopic irregularities in material surfaces.

Once the experimental results of the thermal behavior of the sections had been studied, the equivalent thermal conductivities of each of the layers were determined using a multi criteria optimization method based on DOE [36]. Finally, the optimized equivalent thermal conductivity values in all materials were determined using the Response Surface Optimization search ranges through a MOGA [37]. Firstly, the design variables (input and output parameters) were defined in order to carry out the DOE. Secondly, a response surface for prediction purposes was we developed; and finally, the objectives in the MOGA algorithm were we established. The input parameters are the temperature conditions in the experimental setup, while the output parameters are the equivalent thermal conductivity of each layer. Furthermore, the objective in the MOGA algorithm is the thermal transmittance results obtained experimentally.

\section{Results and Discussion}

\subsection{Experimental Results}

\subsubsection{Thermal Behavior of the Whole Cross-Section}

Figure 4 shows the heat flux for each type of blue roof studied both in dry and wet conditions. As the temperature rises through the temperature ramps, the flux becomes steady as further illustrated in Figure 4. The different durations of the tests depended on the stabilization of the system (see Section 2.2).

The sensors closer to the heat source in the experiments (sensors HF 1 and 2 located at the lower part of the sections) demonstrated higher variability.

An increase in variability is observed in the tests carried out under wet conditions during the final section of the testing, which could be associated with the evaporation process occurring at these elevated temperatures.

The temperature gradient between the bottom and the upper parts of the sections tested exceeded $15^{\circ} \mathrm{C}$ during the last $10 \mathrm{~h}$ of the experiments (Figure 5), granting the stabilization of the system, as per stated in the standards (ISO 8990:1994 [30] and ASTM C1363-05 [31]) used to operate the equipment (see Section 2.2). This gradient represents the difference in temperature between the part of the system nearest to the heat source and the ambient temperature. 


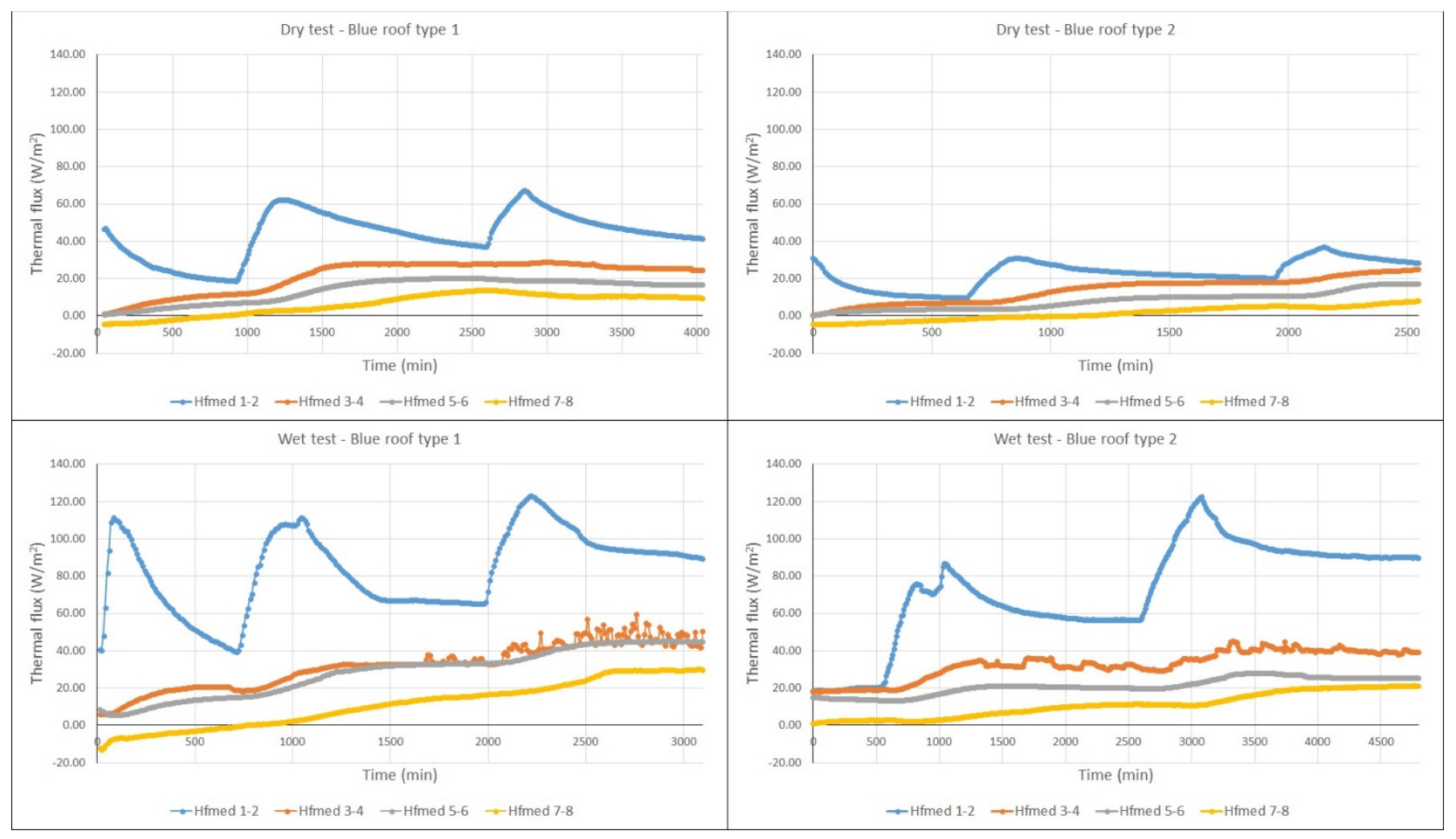

Figure 4. Heat flux in types 1 and 2 of the blue roofs under dry and wet conditions.

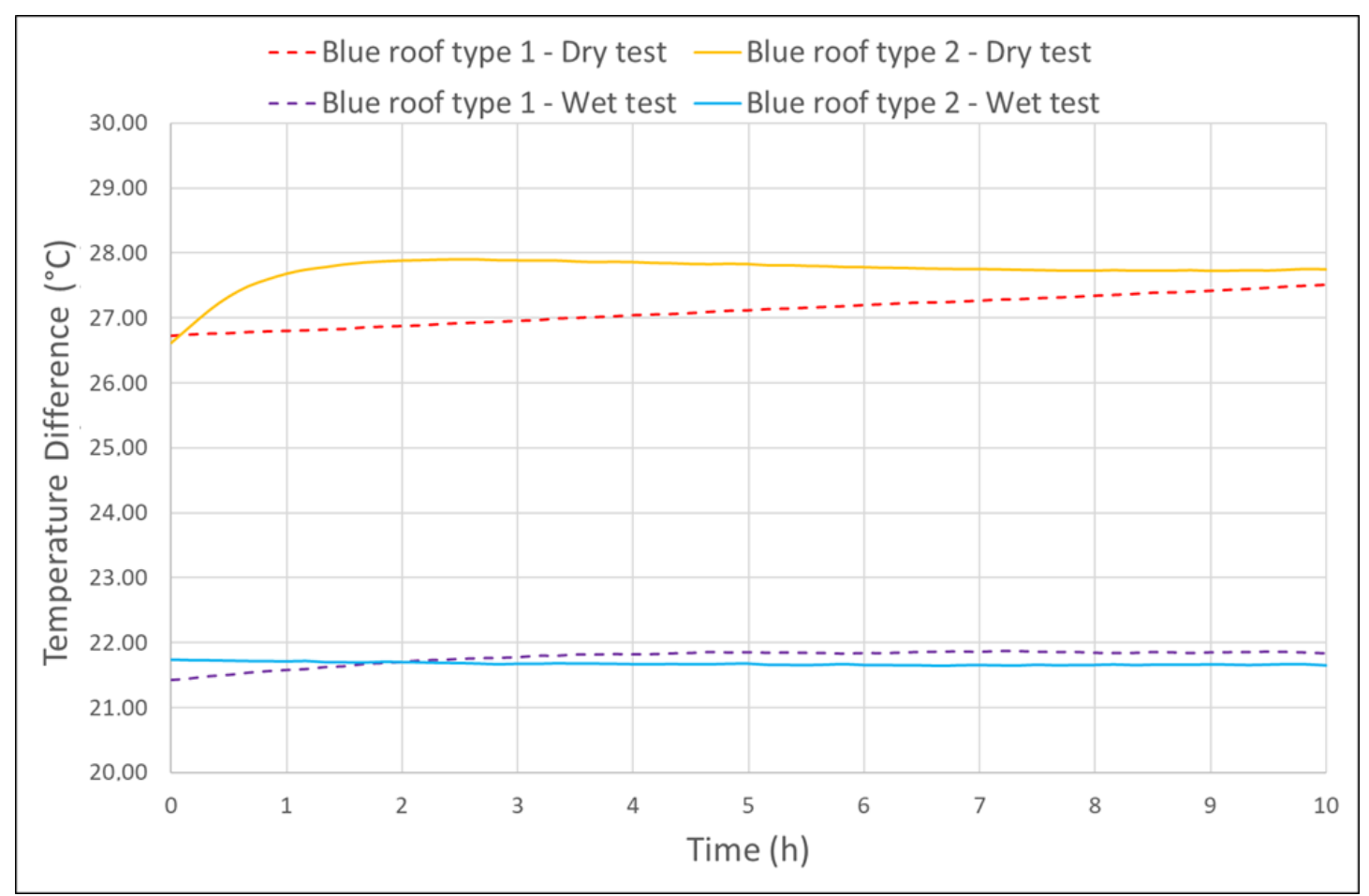

Figure 5. Difference in Temperature between the bottom and upper part of the blue roofs under dry and wet conditions.

Figure 6 exhibits the thermal transmittance values during the last $10 \mathrm{~h}$ of the experiment once the temperature established to operate the system under steady-state conditions was reached $\left(55^{\circ} \mathrm{C}\right)$. The data collected under these conditions and the interval of time 
were representative for the calculation of the thermal performance of the two types of blue roofs tested.

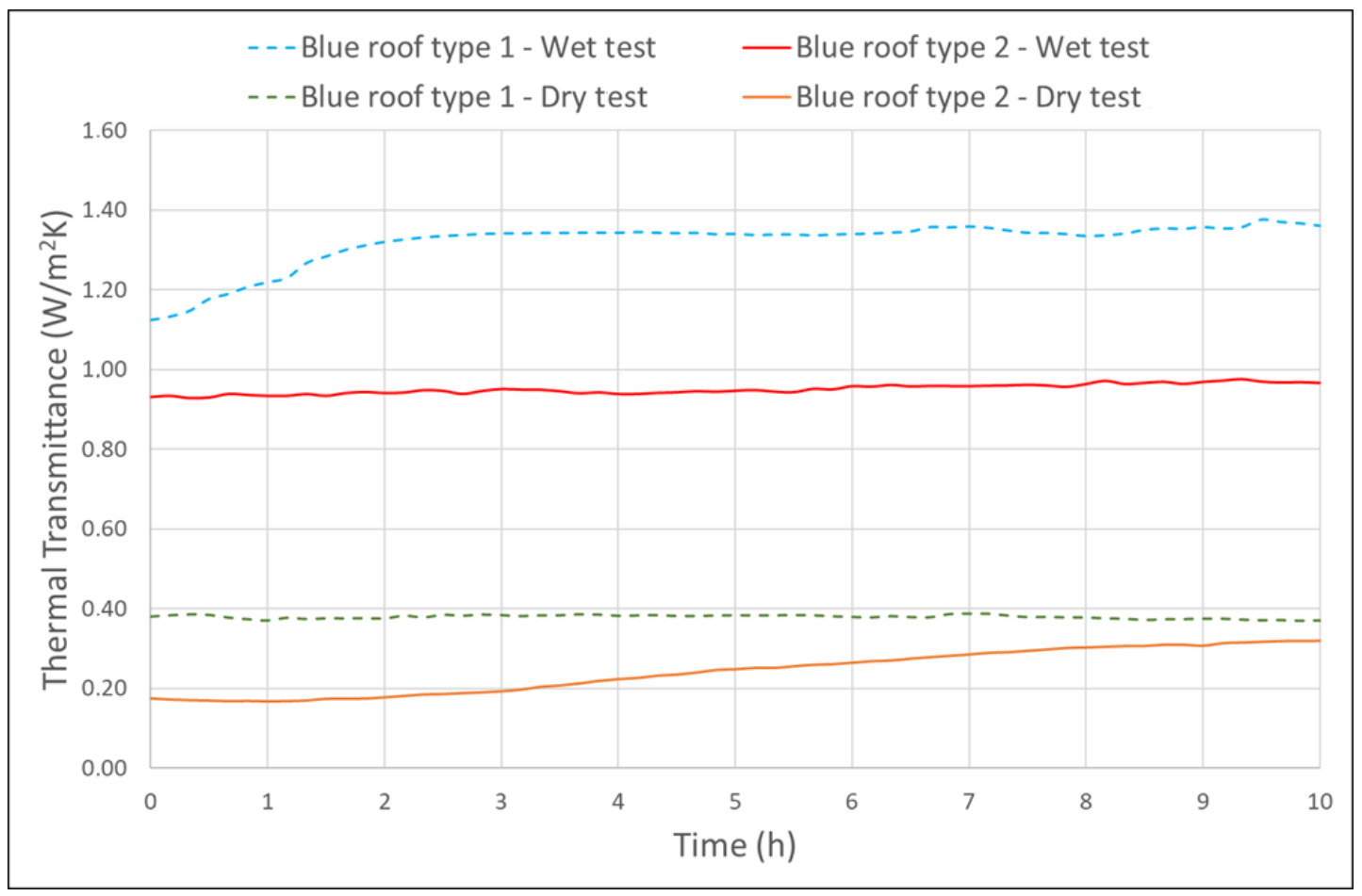

Figure 6. Thermal transmittance during the last $10 \mathrm{~h}$ of the experiments under dry and wet conditions.

The thermal transmittance values registered for each of the tests developed are gathered in Table 1. These figures corresponded to the averaged values of the thermal transmittance once constant (Figure 6).

Table 1. Thermal transmittance values, absolute error and relative error of the blue roofs.

\begin{tabular}{|c|c|c|c|c|c|c|}
\hline & \multicolumn{3}{|c|}{ Dry Test } & \multicolumn{3}{|c|}{ Wet Test } \\
\hline & $\mathrm{U}\left(\mathrm{W} / \mathrm{m}^{2} \mathrm{~K}\right)$ & $\begin{array}{c}\text { Absolute Error } \\
\left(\mathrm{W} / \mathrm{m}^{2} \mathrm{~K}\right)\end{array}$ & $\begin{array}{c}\text { Relative Error } \\
(\%)\end{array}$ & $\mathrm{U}\left(\mathrm{W} / \mathrm{m}^{2} \mathrm{~K}\right)$ & $\begin{array}{c}\text { Absolute Error } \\
\left(\mathrm{W} / \mathrm{m}^{2} \mathrm{~K}\right)\end{array}$ & $\begin{array}{c}\text { Relative Error } \\
(\%)\end{array}$ \\
\hline Blue roof type 1 & 0.38 & 0.01 & 3.30 & 1.19 & 0.16 & 13.99 \\
\hline Blue roof type 2 & 0.23 & 0.04 & 17.02 & 0.93 & 0.02 & 2.34 \\
\hline
\end{tabular}

The type 2 blue roof laboratory model provides the best thermal properties from a potential water-energy nexus viewpoint, integrating GSHP elements into a roof, as shown in Figures 1 and 2. The addition of expanded clay in the sub-base of the cross-section, replacing conventional limestone aggregates, enhances the insulation of the system in contrast with the ambient temperature. On another note, the presence of water, replicating the operation scenario of a blue roof in storm conditions, negatively affects the equivalent thermal conductivity, increasing its value over $60 \%$ in both types of laboratory models.

Tables 1 and 2 show higher values for the relative errors in the dry test of section type 2 and the wet test of section type 1 . This finding is due to the fact that the duration of these tests is longer than the other tests. Therefore, although the heat flux has been steady during the whole test, these tests should have a longer duration. 
Table 2. Equivalent thermal conductivity values, absolute error and relative error for the blue roof laboratory models.

\begin{tabular}{lcccccc}
\hline & \multicolumn{3}{c}{ Dry Test } & & Wet Test \\
\cline { 2 - 8 } & $\lambda_{\text {eq }} \mathbf{( W / m K )}$ & $\begin{array}{c}\text { Absolute Error } \\
\mathbf{( W / m K )}\end{array}$ & $\begin{array}{c}\text { Relative Error } \\
\mathbf{( \% )}\end{array}$ & $\boldsymbol{\lambda}_{\text {eq }} \mathbf{( W / m K )}$ & $\begin{array}{c}\text { Absolute Error } \\
\mathbf{( W / m K )}\end{array}$ & $\begin{array}{c}\text { Relative Error } \\
\mathbf{( \% )}\end{array}$ \\
\hline Blue roof type 1 & 0.23 & 0.01 & 3.30 & 0.71 & 0.10 & 14.32 \\
Blue roof type 2 & 0.14 & 0.02 & 17.02 & 0.56 & 0.01 & 2.34 \\
\hline
\end{tabular}

3.1.2. Effect of the Expanded Clay on the Thermal and Hydraulic Behaviors of Blue Roofs

The effect of the addition of expanded clay in the sub-base layer is discussed in further detail in the analysis of the thermal transmittance in this particular layer within the cross-section. Table 3 shows the comparison between the two types of materials utilized, revealing similar behaviors under dry conditions, which are slightly better than the blue roof type containing limestone aggregates (type 1). However, the expanded clay (type 2 ) evidences a superior performance under wet conditions, displaying similar behaviors in both dry and wet conditions (Table 3 ). The aggregate layer in type 1 produces an increase of $64.9 \%$ in the thermal transmittance.

Table 3. Comparison of thermal transmittance values in the first layer.

\begin{tabular}{|c|c|c|c|c|c|c|}
\hline & \multicolumn{3}{|c|}{ Dry Test } & \multicolumn{3}{|c|}{ Wet Test } \\
\hline & $\mathrm{U}\left(\mathrm{W} / \mathrm{m}^{2} \mathrm{~K}\right)$ & $\begin{array}{l}\text { Absolute Error } \\
\left(\mathrm{W} / \mathrm{m}^{2} \mathrm{~K}\right)\end{array}$ & $\begin{array}{l}\text { Relative } \\
\text { Error (\%) }\end{array}$ & $\mathrm{U}\left(\mathrm{W} / \mathrm{m}^{2} \mathrm{~K}\right)$ & $\begin{array}{l}\text { Absolute Error } \\
\left(\mathrm{W} / \mathrm{m}^{2} \mathrm{~K}\right)\end{array}$ & $\begin{array}{l}\text { Relative } \\
\text { Error (\%) }\end{array}$ \\
\hline Blue roof type 1 (arid) & 2.65 & 0.07 & 2.49 & 4.37 & 0.14 & 3.16 \\
\hline $\begin{array}{l}\text { Blue roof type } 2 \\
\text { (expanded clay) }\end{array}$ & 2.95 & 0.25 & 8.37 & 2.96 & 0.03 & 0.89 \\
\hline
\end{tabular}

On the other hand, an additional $2.0 \pm 0.1 \mathrm{~L}$ of water were required to keep the level of water up to the surface layer in the type 2 section (expanded clay). Given that the volume occupied by the expanded clay is $41.6 \pm 0.2 \mathrm{~L}$, this implies that the water storage capacity of the type 2 roof is $4.8 \%$ higher than the type 1 roof. This means that type 2 could store a surplus of water per $\mathrm{m}^{2}$ of $7.2 \pm 0.2 \mathrm{~L}$ in comparison with type 1 .

\subsubsection{Assessment of the Results within the Context of the Spanish Technical Building Code}

The Spanish Technical Building Code (CTE in its Spanish acronym) (see A-Nomenclature in Appendix A) is the set of standards that establish the requirements for buildings regarding security and livability [38]. The Basic Document HE Energy Saving states that the conditions must be accomplished by the building envelope [39], determining the thermal transmittance of its various elements for each climatic zone in Spain. Table 4 shows the threshold values for the thermal transmittance of the building envelope under each climatic area. All values were estimated for an absorptivity of 0.55 .

Table 4. Threshold values for the thermal transmittance in roofs directly in contact with outdoor conditions based on the Spanish CTE.

\begin{tabular}{cccccc}
\hline \multirow{2}{*}{ Element } & \multicolumn{5}{c}{ Climatic Zone } \\
\cline { 2 - 6 } & A & B & C & D & E \\
\hline $\begin{array}{c}\text { Covers in contact with } \\
\text { outside airU }\left(\mathrm{W} / \mathrm{m}^{2} \mathrm{~K}\right)\end{array}$ & 0.50 & 0.44 & 0.40 & 0.35 & 0.33 \\
\hline
\end{tabular}

The climate zones are defined according to the climatic severity of the different areas [40]. It is calculated using an average statistical range of temperatures during the winter and summer months for each zone [41]. 
Consequently, the type 1 blue roof is compatible with the climatic zones A, B and C based on its performance under dry conditions $\left(\mathrm{U}_{1} \mathrm{dry}=0.38 \mathrm{~W} / \mathrm{m}^{2} \mathrm{~K}\right)$ if compared with the threshold values in Table 4. On the contrary, under dry conditions the type 2 model accomplishes thermal transmittance values for all climatic zones within the range displayed in Table $4\left(\mathrm{U}_{2}{ }^{\mathrm{dry}}=0.23 \mathrm{~W} / \mathrm{m}^{2} \mathrm{~K}\right)$.

However, none of the laboratory models tested under wet conditions in this research meet the limit values established by the Spanish CTE. Nevertheless, this outcome must be put into context by the fact that all roofs have an extra bottom layer acting as a structural element that often improves the thermal properties of the building envelope. Therefore, more research would be recommended with the aim of assessing the effect of blue roofs operating under wet conditions, including the structural element underneath the crosssection of the types studied in this article.

\subsection{Numerical Results}

A sensitivity analysis of the mesh was carried out in order to obtain a better correlation between the experimental values and the numerical model. It was observed that the most influential parameter is the face sizing element, with a lesser impact of the parameters that define the inflation of the mesh at the interface (Figure 7a). The influence of the face sizing element on the results of the thermal transmittance of the total section was determined using DOE. The optimum mesh size was determined to be $10 \mathrm{~mm}$ based on these results (Figure $7 \mathrm{~b}$ ).

A new DOE analysis was carried out using the thermal conductivities of each of the materials used in the standard sections of the blue roofs as input parameters. Table 5 shows the search ranges for the equivalent thermal conductivity values of the materials forming the sections studied. The thermal conductivity values provided by the manufacturers were implemented in order to establish the search ranges for the dry tests. Conversely, the reference values used by other authors were used for the wet scenario [25,42].

Table 5. Search ranges of the thermal conductivities of materials.

\begin{tabular}{ccccc}
\hline & \multicolumn{2}{c}{ Dry Test } & \multicolumn{2}{c}{ Wet Test } \\
\hline $\begin{array}{c}\text { Thermal Conductivity } \\
(\mathbf{W} / \mathbf{m K})\end{array}$ & Lower Bound & Upper Bound & Lower Bound & Upper Bound \\
\hline Atlantis box & 0.13 & 0.17 & 0.15 & 0.60 \\
\hline Limestone aggregates & 1.15 & 1.45 & 1.30 & 2.00 \\
\hline Expanded clay & 0.05 & 0.15 & 0.15 & 0.50 \\
\hline
\end{tabular}

The MOGA algorithm used an objective function to constrain the thermal transmittance values obtained experimentally with the aim of determining the optimized equivalent thermal conductivity values of the layers (see Table 6). Equivalent thermal conductivities were established using these search values (see Table 1). The results of the equivalent thermal conductivity obtained included the effects of convection and radiation in the holes, as well as the conduction inside the particles.

Table 6. Equivalent thermal conductivity values of the layers.

\begin{tabular}{ccc}
\hline Thermal Conductivity $(\mathbf{W} / \mathbf{m K})$ & Dry Test & Wet Test \\
\hline Atlantis box & $0.145 \pm 0.002$ & $0.56 \pm 0.01$ \\
\hline Limestone aggregates & $1.3 \pm 0.1$ & $1.8 \pm 0.1$ \\
\hline Expanded clay & $0.075 \pm 0.007$ & $0.381 \pm 0.006$ \\
\hline
\end{tabular}



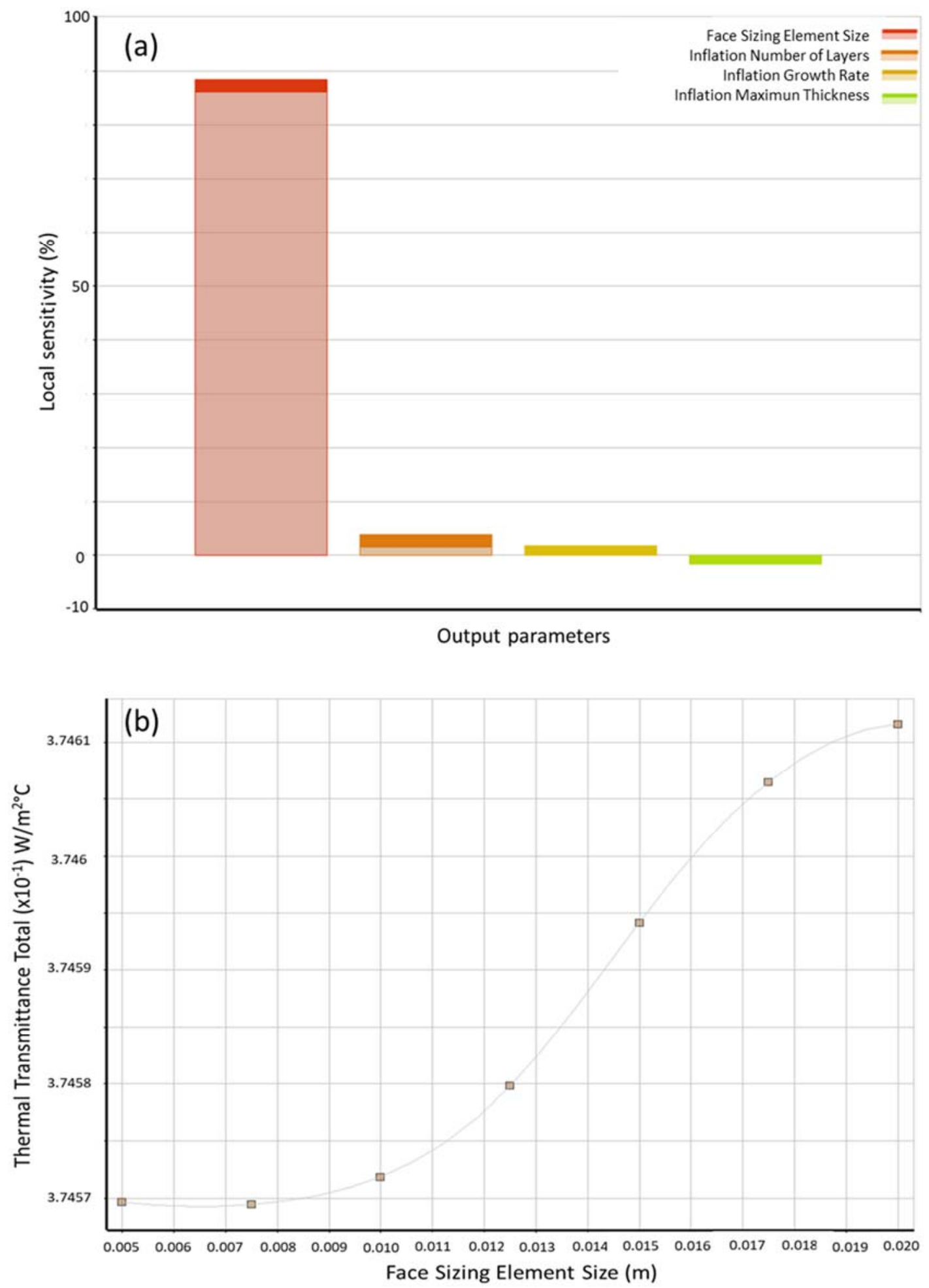

Figure 7. Sensitivity analysis of the mesh. (a) Influence of the parameters defining the mesh. (b) Effect of face sizing element size.

\subsection{Constraints Identified in This Research}

In addition to the dry and wet tests described above, saturated wet tests were carried out. These consisted of keeping a constant level of water up to the surface layer of the blue roof section, as was done by other authors in SUDS thermal studies [16]. The data obtained in these tests showed that the heat flow was transmitted through the water, thus the thermal properties of the different layers forming the blue roof were not available. 
The temperature gradient between the bottom and upper parts of each layer achieved during the experiments conducted did not overcome $15^{\circ} \mathrm{C}$. Therefore, these results are not fully supported by the standards. However, this finding does not imply that the results gained in these experiments are incorrect. Further attention to this particular area may be needed in future research. Nevertheless, the difference in temperature between the bottom layer and the surface layer of the whole section exceeded $15^{\circ} \mathrm{C}$ as can be seen in Figure 5, and this is supported by the standards.

The duration of the experiment was long due to the requirement to reach the steadystate conditions.

\section{Conclusions}

This study provides relevant information about the knowledge gap identified in previous research, which highlighted the need to expand the investigations on heat transfer processes within SUDS, as well as to determine the thermal properties of the materials usually utilized to design and construct SUDS [43], developing the understanding of the water-energy nexus carried out in other SUDS devices [44].

The following conclusions can be drawn from the results of this study:

- The test methodology proposed in this research has been found to be effective in determining the thermal properties of a blue roof. It improves other existing methodologies [24] by being able to assess the thermal properties of the entire section under dry and wet conditions. Furthermore, since this methodology is based on the use of standardized equipment, the results obtained can be easily compared across the world.

- The values obtained for the equivalent thermal transmittance of the blue roofs studied were compared with the values set by the Spanish CTE standards. It was determined that in dry conditions, section type 1 would be compatible with climate zones A, B and $C$, while section type 2 (with expanded clay in the base layer) would be compatible with all climate zones. In contrast, neither of the two types of roofs tested would be compatible with the values set by the CTE by themselves under wet conditions.

- The hydraulic and thermal improvement of the inclusion of expanded clay in the base of the blue roof has been quantified. It increased the hydraulic capacity by $4.8 \%$ and improved the thermal transmittance in both dry and wet conditions. The enhancement was more noticeable under wet conditions, where the limestone aggregate layer in section type 1 increased its thermal transmittance value by $64.9 \%$.

- It was found that the presence of water increased the equivalent thermal conductivity in both sections by $60 \%$. This worsened the thermal insulation capacity of both sections.

- The experimental data were used to carry out a numerical analysis in Ansys. With this analysis, the equivalent thermal conductivities of each of the layers that form the blue roof have been determined. With these results, scale alterations can be made in future designs using numerical models.

Following this hybrid methodology, based on the combination of numerical simulations and experimental tests, several future steps in this research area are proposed as follows:

(1) Development of further laboratory tests, analyzing other SUDS techniques.

(2) Advancement of improvements in the proposed methodology.

(3) Application of numerical modelling to study the appropriate thermal behavior of SUDS, achieving optimized designs.

(4) Continuation of the research area initiated by other authors such as Congedo et al. [45], applying it to a case study in the field.

(5) Development of field experiments, monitoring the thermal behavior of SUDS, using these data to validate the numerical models. 
Author Contributions: The team has contributed towards the following sections of the research presented in this article: Conceptualization, F.P.Á.-R., L.A.S.-F. and M.H.-T.; methodology, F.P.Á.-R., C.R.-M. and M.H.-T.; software, F.P.Á.-R. and C.R.-M.; validation, F.P.Á.-R., C.R.-M. and A.M.S.-I.; formal analysis, F.P.Á.-R., C.R.-M. and M.H.-T.; investigation, F.P.Á.-R., L.A.S.-F., C.R.-M. and M.H.-T.; resources, F.P.Á.-R. and L.A.S.-F.; data curation, C.R.-M., A.M.S.-I. and M.H.-T.; writing-original draft preparation, F.P.Á.-R., C.R.-M., L.A.S.-F. and A.M.S.-I.; writing-review and editing, F.P.Á.-R., C.R.-M., L.A.S.-F. and A.M.S.-I.; supervision, F.P.Á.-R. and L.A.S.-F.; project administration, F.P.Á.-R., L.A.S.-F. and C.R.-M.; funding acquisition, F.P.Á.-R., L.A.S.-F. and C.R.-M. All authors have read and agreed to the published version of the manuscript.

Funding: This investigation was funded by the FICYT through the GRUPIN project, grant number SV-PA-21-AYUD/2021/51328, co-financed with EU FEDER funds. Carlos Rey-Mahía would like to thank the University of Oviedo for the Predoctoral Grant with reference PAPI-21-PF-23.

Institutional Review Board Statement: Not applicable for studies not involving humans or animals.

Informed Consent Statement: Not applicable.

Data Availability Statement: The data presented in this study are available on request from the corresponding author. The data are not publicly available due to an ongoing research project, which provided part of the funding of this study.

Acknowledgments: The authors thank SUDS S.L. and Atlantis Corp for providing the lightweight modular tank structural systems used in one of the cross-sections of the laboratory models. They also thank Weber Saint-Gobain for the technical support and the materials contributed for the realization of the blue roof models. Finally, they thank Swanson Analysis Inc. for the use of the university research version of the ANSYS $2021 \mathrm{R} 2$ program in this paper.

Conflicts of Interest: The authors declare no conflict of interest. The funders had no role in the design of the study; in the collection, analyses, or interpretation of data; in the writing of the manuscript, or in the decision to publish the results.

\section{Appendix A. Nomenclature}

Acronyms
CTE
DOE
EU
FEM
GSHP
HIE
LID
MOGA
NBS
PPS
SCM
SDGs
SUDS
WSUD
Symbols
U
$\Delta \mathrm{T}$
$\Phi$
$R_{\text {down }}$
$R_{\text {up }}$
$R_{\text {tot }}$
$a$
$\lambda_{\text {eq }}$
$\mathrm{Q}_{\mathrm{TCC}}$
$\mathrm{k}_{\mathrm{TCC}}$
$\mathrm{T}_{\mathrm{c}, \mathrm{T}} ; \mathrm{T}_{\mathrm{c}, \mathrm{C}}$

Spanish Technical Building Code (Spanish acronym)

Design of Experiments

European Union

Finite Element Analysis

Ground Source Heat Pump

Heat Island Effect

Low Impact Development

Multi-Objective Genetic Algorithm methodologies

Nature-based Solutions

Permeable Pavement Systems

Stormwater Constructed Measures

Sustainable Development Goals

Sustainable Urban Drainage Systems

Water Sensitive Urban Design

thermal transmittance $\left(\mathrm{W} / \mathrm{m}^{2} \mathrm{~K}\right)$

temperature differential $(\mathrm{K})$

average heat flux $\left(\mathrm{W} / \mathrm{m}^{2}\right)$

thermal resistance at the bottom part of the box $\left(\mathrm{m}^{2} \mathrm{~K} / \mathrm{W}\right)$

thermal resistance of the upper part of the blue roof $\left(\mathrm{m}^{2} \mathrm{~K} / \mathrm{W}\right)$

total thermal resistance $\left(\mathrm{m}^{2} \mathrm{~K} / \mathrm{W}\right)$

total thickness of the blue roof model (m)

equivalent thermal conductivity $(\mathrm{W} / \mathrm{mK})$

heat flux per unit area in the interlayer $\left(\mathrm{W} / \mathrm{m}^{2}\right)$

thermal contact conductance coefficient $\left(\mathrm{W} / \mathrm{m}^{2}{ }^{\circ} \mathrm{C}\right)$

temperatures of the contacts points $\left({ }^{\circ} \mathrm{C}\right)$ 


\section{References}

1. Melchiorri, M.; Pesaresi, M.; Florczyk, A.; Corbane, C.; Kemper, T. Principles and Applications of the Global Human Settlement Layer as Baseline for the Land Use Efficiency Indicator-SDG 11.3.1. IJGI 2019, 8, 96. [CrossRef]

2. World Economic Forum. Inspiring Future Cities \& Urban Services Shaping the Future of Urban Development E Services Initiative; World Economic Forum: Colony, Switzerland, 2016.

3. Woods-Ballard, B.; Wilson, S.; Udale-Clarke, H.; Illman, S.; Scott, T.; Ashley, R.; Kellagher, R. The SuDS Manual; CIRIA: London, UK, 2015; 165p.

4. Charlesworth, S.M.; Faraj-Llyod, A.S.; Coupe, S.J. Renewable energy combined with sustainable drainage: Ground source heat and pervious paving. Renew. Sustain. Energy Rev. 2017, 68, 912-919. [CrossRef]

5. Price, S.J. 3D ground-use optimization for sustainable urban development planning. A case-study from Earls Court, London, UK Tunn. Undergr. Space Technol. 2018, 21, 144-164. [CrossRef]

6. United Nations. La Agenda 2030 y los Objetivos de Desarrollo Sostenible: Una oportunidad para América Latina y el Caribe; United Nations: Santiago, Chile, 2018; pp. 15-79.

7. Sarbu, I.; Sebarchievici, C. General review of ground-source heat pump systems for heating and cooling of buildings. Energy Build. 2014, 70, 441-454. [CrossRef]

8. Roca, M.; Escarameia, M.; Gimeno, O.; Vilder, L.; Simm, J.; Horton, B.; Thorne, C. Green Approaches in River Engineering: Supporting Implementation of Green Infrastructure; NERC: Atlanta, GA, USA, 2017.

9. Perales-Momparler, S.; Andrés-Doménech, I.; Hernández-Crespo, C.; Vallés-Morán, F.; Martín, M.; Escuder-Bueno, I.; Andreu, J The role of monitoring sustainable drainage systems for promoting transition towards regenerative urban built environments: A case study in the Valencian region, Spain. J. Clean. Prod. 2017, 163, 113-124. [CrossRef]

10. Fletcher, T.D.; Shuster, W.; Hunt, W.F.; Ashley, R.; Butler, D.; Arthur, S.; Trowsdale, S.; Barraud, S.; Semadeni-Davies, A.; Mikkelsen, P.S. SUDS, LID, BMPs, WSUD and more-The evolution and application of terminology surrounding urban drainage. Urban Water J. 2015, 12, 525-542. [CrossRef]

11. Niet, T.; Arianpoo, N.; Kuling, K.; Wright, A.S. Embedding the United Nations sustainable development goals into energy systems analysis: Expanding the food-energy-water nexus. Energy Sustain. Soc. 2021, 11, 1. [CrossRef]

12. Huckleberry, J.K.; Potts, M.D. Constraints to implementing the food-energy-water nexus concept: Governance in the Lower Colorado River Basin. Environ. Sci. Policy 2019, 92, 289-298. [CrossRef]

13. Tota-Maharaj, K.; Scholz, M.; Coupe, S.J. Modelling Temperature and Energy Balances within Geothermal Paving Systems. Road Mater. Pavement Des. 2011, 12, 315-344. [CrossRef]

14. Del-Castillo-García, G.; Borinaga-Treviño, R.; Sañudo-Fontaneda, L.A.; Pascual-Muñoz, P. Influence of pervious pavement systems on heat dissipation from a horizontal geothermal system. Eur. J. Environ. Civ. Eng. 2013, 17, 956-967. [CrossRef]

15. Faraj-Lloyd, A.; Charlesworth, S.M.; Coupe, S.J. Sustainable Drainage Systems and Energy: Generation and Reduction. Sustainable Surface Water Management, 1st ed.; Wiley: Hoboken, NJ, USA, 2016; pp. 177-192.

16. Andrés-Valeri, V.C.; Sañudo-Fontaneda, L.A.; Rey-Mahía, C.; Coupe, S.J.; Alvarez-Rabanal, F.P. Thermal Performance of Wet Swales Designed as Multifunctional Green Infrastructure Systems for Water Management and Energy Saving. Proceedings 2018, 2, 1433. [CrossRef]

17. Sañudo-Fontaneda, L.A.; Roces-García, J.; Coupe, S.J.; Barrios-Crespo, E.; Rey-Mahía, C.; Álvarez-Rabanal, F.P.; Lashford, C. Descriptive Analysis of the Performance of a Vegetated Swale through Long-Term Hydrological Monitoring: A Case Study from Coventry, UK. Water 2020, 12, 2781. [CrossRef]

18. Chan, F.K.S.; Griffiths, J.A.; Higgitt, D.; Xu, S.; Zhu, F.; Tang, Y.-T.; Xu, Y.; Thorne, C.R. "Sponge City" in China-A breakthrough of planning and flood risk management in the urban context. Land Use Policy 2018, 76, 772-778. [CrossRef]

19. Shafique, M.; Kim, R. Application of green blue roof to mitigate heat island phenomena and resilient to climate change in urban areas: A case study from Seoul, Korea. J. Water Land Dev. 2017, 33, 165-170. [CrossRef]

20. Shafique, M.; Kim, R.; Rafiq, M. Green roof benefits, opportunities and challenges-A review. Renew. Sustain. Energy Rev. 2018, 90, 757-773. [CrossRef]

21. Stovin, V.; Vesuviano, G.; Kasmin, H. The hydrological performance of a green roof test bed under UK climatic conditions. $J$. Hydrol. 2012, 414-415, 148-161. [CrossRef]

22. Van Niekerk, M.; Greenstone, C.; Hickman, M. Guideline for Designing Green Roof Habitats; Environmental Planning and Climate Protection Department: Durban, South Africa, 2011.

23. Jato-Espino, D.; Sañudo-Fontaneda, L.A.; Andrés-Valeri, V.C. Green Infrastructure: Cost-Effective Nature-Based Solutions for Safeguarding the Environment and Protecting Human Health and Well-Being. Handbook of Environmental Materials Management; Springer International Publishing AG: Berlin/Heidelberg, Germany, 2018; pp. 1-27.

24. Rottmann, M.; Beikircher, T.; Ebert, H.-P. Thermal conductivity of evacuated expanded perlite measured with guarded-hot-plate and transient-hot-wire method at temperatures between $295 \mathrm{~K}$ and $1073 \mathrm{~K}$. Int. J. Therm. Sci. 2020, 152, 106338. [CrossRef]

25. Del Coz Díaz, J.J.; Álvarez Rabanal, F.P.; García Nieto, P.J.; Domínguez Hernández, J.; Rodríguez Soria, B.; Pérez-Bella, J.M. Hygrothermal properties of lightweight concrete: Experiments and numerical fitting study. Constr. Build. Mater. 2013, 40, 543-555. [CrossRef]

26. Bull, J.W. Computer Analysis and Design of Masonry Structures; Saxe-Coburg Publications: Stirling, UK, 2017. 
27. Mayor's Office of Transportatios and Utilities, City of Philadelphia. City of Philadelphia Green Streets Desing Manual; Mayor's Office of Philadelphia: Philadelphia, PA, USA, 2014.

28. Shafique, M.; Kim, R.; Kyung-Ho, K. Green Roof for Stormwater Management in a Highly Urbanized Area: The Case of Seoul, Korea. Sustainability 2018, 10, 584. [CrossRef]

29. Rashad, A.M. Lightweight expanded clay aggregate as a building material—An overview. Constr. Build. Mater. 2018, 170, 757-775. [CrossRef]

30. Thermal Insulation. Determination of Steady-State Thermal Transmission Properties. Calibrated and Guarded Hot Box. ISO 8990-1994; ISO: Geneva, Switzerland, 2019.

31. Standard Test Method for the Thermal Performance of Building Assemblies by Means of a Hot Box Apparatus. ASTM C1363-05; ASTM: West Conshohocken, PA, USA, 2019.

32. Mechanical User's Guide; Release 19.2.; Ansys®Academic Research Mechanical: Canonsburg, PA, USA, 2019.

33. Building Components and Building Elements-Thermal Resistance and Thermal Transmittance-Calculation Methods. ISO 6946:2017; ISO: Geneva, Switzerland, 2017.

34. Del Coz-Díaz, J.J.; Álvarez-Rabanal, F.P.; Alonso-Martínez, M.; Martínez-Martínez, J.E. Thermal Inertia Characterization of Multilayer Lightweight Walls: Numerical Analysis and Experimental Validation. Appl. Sci. 2021, 11, 5008. [CrossRef]

35. Parikh, M.; Shah, S.; Vaghela, H.; Parwani, A.K. A comprehensive experimental and numerical estimation of thermal contact conductance. Int. J. Therm. Sci. 2022, 172, 107285. [CrossRef]

36. Antony, J. Design of Experiments for Engineers and Scientists; Butterworth-Heinemann: New York, NY, USA; Elsevier: Amsterdam, The Netherlands, 2014.

37. Acharya, S.; Saini, T.R.S.; Sundaram, V.; Kumar, H. Selection of optimal composition of MR fluid for a brake designed using MOGA optimization coupled with magnetic FEA analysis. J. Intell. Mater. Syst. Struct. 2021, 32, 1831-1854. [CrossRef]

38. Ministerio de la Vivienda. Real Decreto 314/2006, de 17 de Marzo, por el Que se Aprueba el Código Técnico de la Edificación; Government of Spain: Madrid, Spain, 2006.

39. Ministerio de Transporte, Movilidad y Agenda Urbana. DA DB HE-1 Cálculo de Parámetros Característicos de la Envolvente; Código Técnico de la Edificación (CTE): Madrid, Spain, 2020.

40. Ministerio de Transporte, Movilidad y Agenda Urbana. DB HE Ahorro de Energía; Código Técnico de la Edificación (CTE): Madrid, Spain, 2019.

41. Roa-Fernández, J.; Galán-Marín, C.; Rojas-Fernández, J.; Rivera-Gómez, C. Análisis del Comportamiento del Patio Como Factor Significativo de la Porosidad Urbana en el Contexto de los Cascos Históricos; REHABEND: Caceres, Spain, 2018 ; Volume 12.

42. Del Coz Díaz, J.J.; Álvarez-Rabanal, F.P.; Gencel, O.; García Nieto, P.J.; Alonso-Martínez, M.; Navarro-Manso, A.; Prendes-Gero, B. Hygrothermal study of lightweight concrete hollow bricks: A new proposed experimental-numerical method. Energy Build. 2014, 70, 194-206. [CrossRef]

43. Rey-Mahía, C.; Sañudo-Fontaneda, L.A.; Andrés-Valeri, V.C.; Álvarez-Rabanal, F.P.; Coupe, S.J.; Roces-García, J. Evaluating the Thermal Performance of Wet Swales Housing Ground Source Heat Pump Elements through Laboratory Modelling. Sustainability 2019, 11, 3118. [CrossRef]

44. Yildiz, A.; Stirling, R.A. Thermo-hydrological behaviour of green infrastructure: A comparative field and laboratory study. Geomech. Energy Environ. 2021, 25, 100219. [CrossRef]

45. Congedo, P.M.; Colangelo, G.; Starace, G. CFD simulations of horizontal ground heat exchangers: A comparison among different configurations. Appl. Therm. Eng. 2012, 33-34, 24-32. [CrossRef] 